\title{
The nutritive value for ruminants of faba bean (Vicia faba) seeds and naked oat (Avena nuda) grain cultivated in an organic farming system
}

\author{
P. Micek ${ }^{1,3}$, B. Kulig ${ }^{2}$, P. Woźnica ${ }^{1}$ and A. Sajdak ${ }^{2}$ \\ University of Agriculture in Krakow, \\ ${ }^{1}$ Department of Animal Nutrition and Feed Management, \\ ${ }^{2}$ Department of Crop Production \\ Al. Mickiewicza 21, 31-120 Krakow, Poland
}

(Received 4 April 2012; revised version 10 September 2012; accepted 10 December 2012)

\begin{abstract}
The aim of the study was to determine the yield per ha, chemical composition, in vitro true digestibility (IVTD), and nutritive value of faba bean seeds and naked oat grain grown in pure sowing or in mixtures (effect of cultivation method) under organic farming conditions. The experiment was carried out on two faba bean cultivars (Olga, a low tannin, traditional variety, and Optimal, a high tannin variety with terminal inflorescences), and naked oat (cv. Polar). The proportions of faba been to oat in sowing mixtures, in relation to optimum sowing density for each species grown in a pure stand (taken as 100\%), were 0:100, 25:75, 50:50, 75:25, and 100:0, respectively. The highest grain yield $(3.12 \mathrm{t} / \mathrm{ha})$ and yield of crude protein $(978 \mathrm{~kg} / \mathrm{ha})$ per ha were obtained from the mixture of $75 \%$ faba bean (Optimal) and $25 \%$ oat. Increasing the proportion of oat in the mixtures decreased their crude protein content with little impact on other nutrient contents, in vitro true digestibility, UFL and PDI values. In faba bean, greater differences among analysed parameters were observed between cultivars than between cultivation methods.
\end{abstract}

KEY WORDS: faba bean, oat, seeds, nutritive value, organic farming

\section{INTRODUCTION}

Intensive development of organic farming in Poland began in 1999/2000, when Polish farmers received the first subsidies for organic agriculture and cost control.

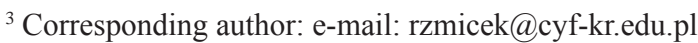


In the organic agriculture system, cereal-legume mixtures are used to enrich animal diets in protein, without the use of nitrogen fertilization and chemical plant protection (Pastuszewska, 1997; Księżak, 2007). These kinds of mixtures also have some disadvantages, mainly due to variability of yield and concentration of nutrients in seeds as an effect of different reactions of plant species to site conditions. Variation in the nutritive value of cereal-legume seeds is such that it handicaps the precise balancing of rations for animals, reduces the efficiency of animal feeding, and creates difficulties in adapting to the specificities of crop plant production (Borowiecki and Księżak, 2000).

Protein from legumes is a good complement to cereals, hence mixtures containing lupine, faba bean or pea have a high biological value (Pastuszewska, 1997; Księżak, 2007). Faba bean seeds can be successfully used as a compound of high-protein concentrates for adult animals. According to Bidwell-Porębska and Piotrowski (1991), concentrate mixtures with a $10 \%$ or $25 \%$ share of ground faba beans are also good feeds for calves and permit maintaining satisfactory body weight gain. In turn, Maierhofer et al. (2002) using a total mixture ration (TMR) with the concentrate containing $40 \%$ extracted soyabean meal or $50 \%$ faba bean meal plus $10 \%$ soyabean meal (both in a TMR that had a similar nutritive value) showed that bulls had similar average daily gains in both groups. Nonetheless, the presence of antinutritional compounds in faba bean seeds, mostly tannins and glycosides, limits their usefulness in rations, especially for growing animals (Baranowski, 2005).

Important progress in the breeding of faba bean cultivars has been observed in Poland since 2002. Seven low-tannin cultivars have been registered, but the national registry of faba bean still contains indeterminate (traditional) and determinate (with terminal inflorescence) cultivars with high tannin levels (Kulig and Zając, 2007).

The lower seed yield of naked oat cultivated in pure sowing and lower yielding of mixtures with naked in comparison with hulled oat are associated with the low 1000 grain weight and smaller post-emergence plant density of naked oat (Piech et al., 2000). The introduction of naked forms of barley and oats instead of hulled ones has been beneficial, however, in terms of protein yield and energy value of seeds for pigs (Noworolnik and Leszczynska, 2004), and negative in terms of grain yield (Piech et al., 2000; Noworolnik and Leszczyńska, 2004).

Oat has a distinctly different chemical composition from other cereal grains. It contains twice as much fat as rye, barley, and wheat. The fat content in the grain of hulled oats averages about $5.2 \%$, whereas in naked oats, $7.9 \%$. There is a lack of information in the scientific literature about the usefulness of naked oats for cultivation in mixtures with new varieties of faba bean and on the nutritive value of seeds originating from organic farming. 
The aim of this study was to determine the yield per ha, chemical composition, in vitro true digestibility, and nutritive value of faba bean seeds and naked oat grain grown in pure sowing or obtained from mixtures grown under organic farming conditions.

\section{MATERIAL AND METHODS}

\section{Experimental design}

Oat and faba bean were grown in pure stands or in mixtures (effect of cultivation method). The experiment was conducted on one cultivar of naked oat (Polar) and two cultivars of faba bean: Olga (indeterminate, low-tannin) and Optimal (determinate, high-tannin). The proportions of oat and faba bean seeds in sowing mixtures in relation to optimum sowing density for each species grown in pure stand taken as $100 \%$ (oat 500 pieces $/ \mathrm{m}^{2}$, faba bean cv. Olga 50 pieces $/ \mathrm{m}^{2}$, and $\mathrm{cv}$. Optimal 70 pieces $/ \mathrm{m}^{2}$ ) were $0: 100,25: 75,50: 50,75: 25$, or 100:0, respectively. The field experiment was carried out at the Experimental Station in Prusy near Krakow using a randomized block design with four replications (Table 1). A single plot area was $10 \mathrm{~m}^{2}$. The applied phosphoruspotassium fertilization was in accordance with organic agriculture rules (phosphate powder and potassium sulphate). Neither nitrogen fertilization nor pest control chemicals were used. Weeds were controlled mechanically.

Table 1. Experimental design

\begin{tabular}{lccc}
\hline & \multicolumn{3}{c}{ Species share in the mixture, \% } \\
\cline { 2 - 4 } Species & oat & Olga & Optimal \\
\cline { 2 - 4 } Variety & Polar & $100\left(50\right.$ seeds $\left./ \mathrm{m}^{2}\right)$ & $100\left(70\right.$ seeds $\left./ \mathrm{m}^{2}\right)$ \\
Pure stand & $100\left(500\right.$ grains $\left./ \mathrm{m}^{2}\right)$ & & \\
Mixtures & & 25 & \\
M1 & 75 & 50 & \\
M2 & 50 & 75 & 25 \\
M3 & 25 & & 50 \\
M4 & 75 & & 75 \\
M5 & 50 & & \\
M6 & 25 & & \\
\hline
\end{tabular}

Yield and chemical composition

The grain yields of oat and faba bean are presented at 15\% water content. The chemical composition (DM, crude ash, crude protein, crude fibre, ether extract and $\mathrm{N}$-free extractives) of representative samples of seeds separated from mixtures was determined using AOAC (2001) methods. 
In vitro digestibility

In vitro true digestibility (IVTD; Ankom Technology, 2009) of seeds and grains was estimated in a Daisy ${ }^{\mathrm{II}}$ Incubator (Ankom Co, Fairport, NY) based on the Van Soest et al. (1966) procedure. The dried and ground $(1.5 \mathrm{~mm})$ samples of faba bean and oat were placed in filter bags (F57) made from polyester/ polyethylene extruded filaments ( 50 x $55 \mathrm{~mm}$ exterior size). The bags ( 4 jars $\mathrm{x} 4$ replications) were then incubated in an incubation jar in buffered ruminal fluid for $48 \mathrm{~h}$. According to Ankom's recommendations, $0.50 \mathrm{~g}$ of sample per bag were weighed. Rumen fluid was collected by a rumen cannula from two dry Holstein-Friesian cows fed $5 \mathrm{~kg} \mathrm{~d}^{-1}$ of meadow hay and $3.3 \mathrm{~kg} \mathrm{~d}^{-1}$ of concentrate mixture with mineral supplementation. The rumen fluid was collected directly before assessments. After incubation, the jars were drained and the bags rinsed thoroughly with cold tap water. The bags with residues were boiled for $75 \mathrm{~min}$ in neutral detergent solution (in an Ankom ${ }^{220}$ apparatus). After the solution was removed, $2000 \mathrm{ml}$ of hot $\left(90^{\circ}-100^{\circ} \mathrm{C}\right) \mathrm{H}_{2} \mathrm{O}$ and $4.0 \mathrm{ml}$ of $\alpha$-amylase were used in the first and second rinses of bags. The bags were then dried and weighed.

\section{Nutritive value}

The nutritive value for ruminants of oat and faba bean seeds was calculated in French system units (INRA), using PrevAlim v. 3.0 software. Calculations were based on our own determination of the chemical composition of samples and on standard coefficients of ruminal degradability, intestinal digestibility of protein, and total tract digestibility of organic matter (INRA, 2007). Energy content was expressed as milk feeding units (UFL) and meat feeding units (UFV), which are the net energy content of lactation or growth relative to that of the reference barley. The protein content of seeds was expressed as protein truly digested in the small intestine (PDI), where rumen available energy (PDIE) or rumen available nitrogen (PDIN) were limiting for microbial growth in the rumen.

\section{Statistical analysis}

Data were analysed statistically using one-way analysis of variance (ANOVA procedure) to assess the effect of share of species in the mixture (SAS, 19992000). The following model equation was used:

$$
\mathrm{Y}_{\mathrm{it}}=\mu+\tau_{\mathrm{i}}+\varepsilon_{\mathrm{it}}
$$

where: $\mathrm{Y}_{\text {it }}$ - the random variable that represents the response from the ${ }^{\text {th }}$ observation of the $\mathrm{i}^{\text {th }}$ treatment; $\mu$ - the overall mean; $\tau_{\mathrm{i}}$ - the effect of the $\mathrm{i}^{\text {th }}$ treatment on the response; $\varepsilon_{\text {it }}$ - independent random variables. 
Means were separated using Duncan's multiple range test. Effects between experimental groups were considered statistically significant at $\mathrm{P} \leq 0.05$. The coefficient of determination $\left(\mathrm{R}^{2}\right)$ and regression equations between the selected variables were also calculated. In the Tables, results are presented as mean values with pooled standard errors.

\section{RESULTS}

The seed and protein yields of oats and faba bean cultivated in pure stand or in mixtures are presented in Table 2 and Figure 1. Sum of protein yield per ha was significantly influenced by the share of faba bean in the mixture as well as by faba bean cultivar. The seed yield of faba bean (both cultivars) grown in pure stands averaged 1.89 tons per ha, whereas that of naked oat, $2.31 \mathrm{t} \cdot \mathrm{ha}^{-1}$.

Table 2. Total seed and protein yield

\begin{tabular}{|c|c|c|c|c|c|c|c|}
\hline \multirow[t]{2}{*}{ Indices } & \multirow{2}{*}{$\begin{array}{c}\text { Origin of } \\
\text { grains/seeds }\end{array}$} & \multicolumn{3}{|c|}{$\begin{array}{l}\text { Seed yield } \\
t \cdot \text { ha }^{-1}\end{array}$} & \multicolumn{3}{|c|}{$\begin{array}{l}\text { Crude protein yield } \\
\mathrm{kg} \cdot \mathrm{ha}^{-1}\end{array}$} \\
\hline & & faba bean & oat & total & faba bean & oat & total \\
\hline \multicolumn{8}{|c|}{ Pure stand } \\
\hline & $\begin{array}{l}\text { oat (Polar) } \\
\text { faba bean }\end{array}$ & - & 2.31 & $2.31^{\mathrm{c}}$ & - & 296 & $296^{e}$ \\
\hline & Olga & 1.95 & - & $1.95^{\mathrm{d}}$ & 579 & - & $579^{d}$ \\
\hline & Optimal & 1.83 & - & $1.83^{\mathrm{d}}$ & 592 & - & $592^{\mathrm{d}}$ \\
\hline \multicolumn{8}{|c|}{ Mixtures } \\
\hline M1 & faba bean & 0.61 & 1.93 & $2.54^{\mathrm{bc}}$ & 464 & 273 & $737^{c}$ \\
\hline M2 & cultivar & 1.09 & 1.77 & $2.86^{\mathrm{ab}}$ & 584 & 247 & $831^{\mathrm{bc}}$ \\
\hline M3 & Olga & 1.66 & 1.26 & $2.92^{\mathrm{a}}$ & 660 & 186 & $846^{\mathrm{bc}}$ \\
\hline M4 & faba bean & 1.01 & 1.80 & $2.81^{\mathrm{ab}}$ & 555 & 253 & $808^{c}$ \\
\hline M5 & cultivar & 1.35 & 1.69 & $3.04^{\mathrm{a}}$ & 702 & 250 & $952^{\mathrm{ab}}$ \\
\hline M6 & Optimal & 1.99 & 1.13 & $3.12^{\mathrm{a}}$ & 804 & 174 & $978^{\mathrm{a}}$ \\
\hline \multirow[t]{2}{*}{ Overall } & Mean & 1.44 & 1.70 & 2.60 & 618 & 251 & 744 \\
\hline & SEM & 0.19 & 0.17 & 0.17 & 56.49 & 24.69 & 57.42 \\
\hline
\end{tabular}

a, b... means within a column with different superscripts are significantly different $(\mathrm{P}<0.05)$

The highest yields of faba bean seeds were recorded in mixtures M3 (oat and faba bean cv. Olga) and M6 (oat and faba bean cv. Optimal; Table 1), where the share of faba bean in the sowing material was $75 \%$ and oat, $25 \%$. These mixtures were also characterized by the highest total protein yield per ha. Increasing the share of oat in the mixture resulted in reduction of total seed and grain yield and protein yield per ha. Nevertheless, even from mixtures with a $75 \%$ share of oat in sowing material, the total seed yield of the mixture was higher than of oat or faba bean crops grown in pure sowing. 
The share of faba bean seeds in total seed and grain yield and crude protein yield of mixtures, regardless of faba bean cultivar, is shown in Figure 1. In both cases, a higher proportion of faba bean in the sowing material resulted in its higher share in the yield, but the results differed for the faba bean cultivars (Table 2).

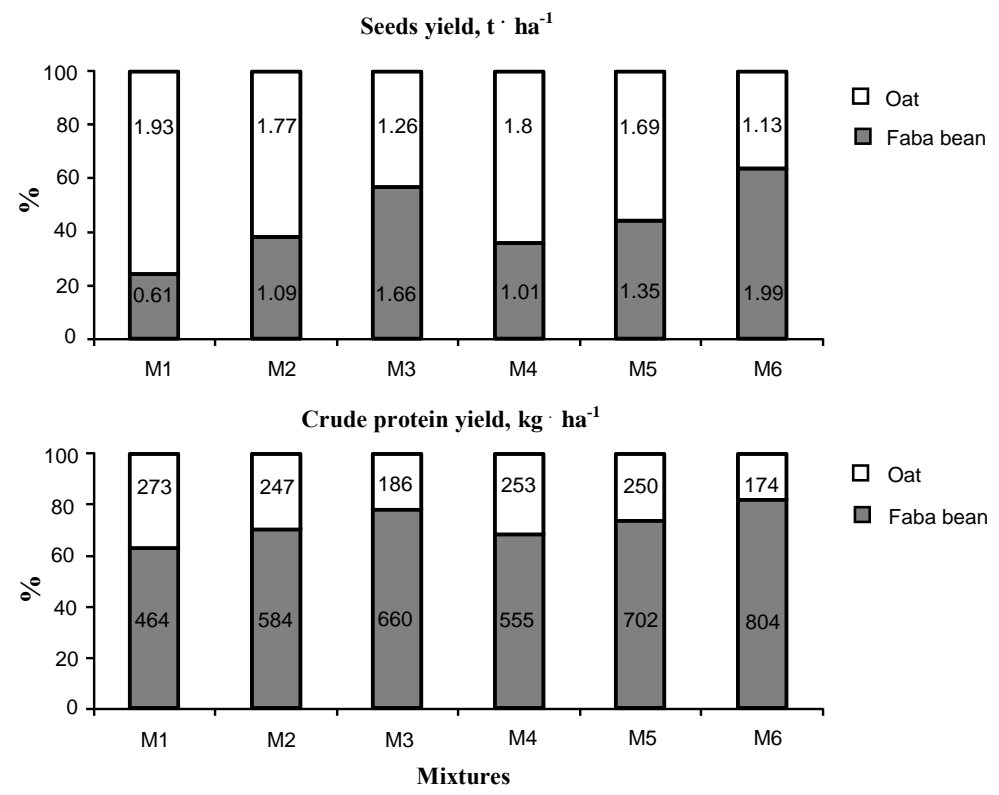

Figure 1. Seed and crude protein yield of the mixtures; values on the bars express absolute seeds yield $\left(\mathrm{t} \cdot \mathrm{ha}^{-1}\right)$ or protein yield $\left(\mathrm{kg} \cdot \mathrm{ha}^{-1}\right)$

The share of Olga cv. seeds in total seed yield ranged from 24\% (M1) to 57\% (M3), whereas for the variety Optimal, it ranged between 36\% (M4) and 64\% (M6). Due to the much higher protein content in faba bean seeds than in oat grain, the proportion of faba bean in the protein yield was at a much higher level, i.e., from $63 \%$ to $78 \%$ and $69 \%$ to $83 \%$, for mixtures with Olga and Optimal cultivars, respectively.

The chemical composition of oat grain and faba bean seeds grown in pure sowing or in mixtures is presented in Table 3. The crude ash content in naked oat grain ranged from 22.1 to $24.4 \mathrm{~g} \cdot \mathrm{kg}^{-1}$ dry matter (DM). The crude protein content (CP) in oat grain grown in pure sowing was $152 \mathrm{~g} \cdot \mathrm{kg}^{-1} \mathrm{DM}$. Cultivation of oat in mixtures with a $25 \%, 50 \%$ and $75 \%$ share of faba bean increased the CP content in oat grain to values reaching $182 \mathrm{~g} \cdot \mathrm{kg}^{-1} \mathrm{DM}(\mathrm{P}<0.05)$. This, the highest, protein content was found in oat grain derived from a mixture with a $75 \%$ share of faba bean (cv. Optimal). 
Table 3. Chemical composition of oat grains and faba bean seeds cultivated in pure stand or in mixtures ${ }^{1}, \mathrm{~g} \cdot \mathrm{kg}^{-1} \mathrm{DM}$

\begin{tabular}{llccccc}
\hline Cultivar & $\begin{array}{c}\text { Origin of } \\
\text { grains/seeds }\end{array}$ & $\begin{array}{c}\text { Crude } \\
\text { ash }\end{array}$ & $\begin{array}{c}\text { Crude } \\
\text { protein }\end{array}$ & $\begin{array}{c}\text { Crude } \\
\text { fibre }\end{array}$ & $\begin{array}{c}\text { Ether } \\
\text { extract }\end{array}$ & $\begin{array}{c}\text { N-free } \\
\text { extractives }\end{array}$ \\
\hline Oat & Pure stand & $22.1^{\mathrm{b}}$ & $152^{\mathrm{c}}$ & $25.7^{\mathrm{c}}$ & $75.0^{\mathrm{a}}$ & $726^{\mathrm{a}}$ \\
Polar & M1 & $22.6^{\mathrm{b}}$ & $167^{\mathrm{b}}$ & $23.7^{\mathrm{c}}$ & $64.8^{\mathrm{a}}$ & $725^{\mathrm{a}}$ \\
& M2 & $22.2^{\mathrm{b}}$ & $164^{\mathrm{bc}}$ & $25.6^{\mathrm{c}}$ & $60.4^{\mathrm{a}}$ & $724^{\mathrm{a}}$ \\
& M3 & $23.2^{\mathrm{ab}}$ & $175^{\mathrm{ab}}$ & $33.6^{\mathrm{a}}$ & $61.9^{\mathrm{a}}$ & $705^{\mathrm{b}}$ \\
& M4 & $22.4^{\mathrm{b}}$ & $167^{\mathrm{b}}$ & $32.6^{\mathrm{ab}}$ & $65.9^{\mathrm{a}}$ & $716^{\mathrm{ab}}$ \\
& M5 & $22.8^{\mathrm{b}}$ & $173^{\mathrm{ab}}$ & $22.9^{\mathrm{c}}$ & $64.0^{\mathrm{a}}$ & $716^{\mathrm{ab}}$ \\
Faba bean & M6 & $24.4^{\mathrm{a}}$ & $182^{\mathrm{a}}$ & $27.2^{\mathrm{bc}}$ & $65.8^{\mathrm{a}}$ & $700^{\mathrm{a}}$ \\
Olga & Mean & 22.8 & 169 & 27.3 & 65.4 & 716 \\
& SEM & 0.51 & 5.46 & 2.21 & 5.97 & 6.86 \\
& Pure stand & $44.2^{\mathrm{a}}$ & $332^{\mathrm{a}}$ & $90.1^{\mathrm{a}}$ & $17.1^{\mathrm{a}}$ & $516^{\mathrm{a}}$ \\
& M1 & $39.1^{\mathrm{b}}$ & $326^{\mathrm{a}}$ & $91.8^{\mathrm{a}}$ & $20.8^{\mathrm{a}}$ & $522^{\mathrm{a}}$ \\
& M2 & $39.8^{\mathrm{ab}}$ & $334^{\mathrm{a}}$ & $81.8^{\mathrm{a}}$ & $18.0^{\mathrm{a}}$ & $526^{\mathrm{a}}$ \\
& M3 & $39.8^{\mathrm{ab}}$ & $335^{\mathrm{a}}$ & $85.9^{\mathrm{a}}$ & $16.0^{\mathrm{a}}$ & $524^{\mathrm{a}}$ \\
Faba bean & Mean & 40.7 & 332 & 87.4 & 18.0 & 522 \\
Optimal & SEM & 0.51 & 5.46 & 2.21 & 5.97 & 6.86 \\
& Mure stand & $41.3^{\mathrm{ab}}$ & $343^{\mathrm{a}}$ & $84.7^{\mathrm{a}}$ & $14.2^{\mathrm{a}}$ & $517^{\mathrm{a}}$ \\
& M5 & $38.0^{\mathrm{b}}$ & $341^{\mathrm{a}}$ & $78.1^{\mathrm{a}}$ & $16.1^{\mathrm{a}}$ & $527^{\mathrm{a}}$ \\
& M6 & $40.4^{\mathrm{ab}}$ & $341^{\mathrm{a}}$ & $83.8^{\mathrm{a}}$ & $17.6^{\mathrm{a}}$ & $517^{\mathrm{a}}$ \\
& Mean & $40.1^{\mathrm{ab}}$ & $343^{\mathrm{a}}$ & $74.6^{\mathrm{a}}$ & $15.3^{\mathrm{a}}$ & $527^{\mathrm{a}}$ \\
& SEM & 40.0 & 342 & 80.3 & 15.8 & 522 \\
\hline
\end{tabular}

a,b,c means within a column with different superscripts are significantly different $(\mathrm{P}<0.05)$

${ }^{1}$ chemical analysis made in samples of grains or seeds separated from mixtures

The opposite trend occurred for ether extract content. The highest content was found in oat grain grown in pure sowing $\left(75 \mathrm{~g} \cdot \mathrm{kg}^{-1} \mathrm{DM}\right)$, however, these differences were not statistically confirmed $(\mathrm{P}>0.05)$. The average content of crude fibre (CF) in oat samples was $27.3 \mathrm{~g} \cdot \mathrm{kg} \mathrm{DM}$, and the highest content was found in oat grain from a $75 \%$ mixture (Olga cv.). Relatively high contents of CF were also found in the grain derived from a $25 \%$ mixture (Optimal cv.). The highest content of $\mathrm{N}$-free extractives (NFE) was found in seeds grown in pure sowing, i.e., $726 \mathrm{~g} \cdot \mathrm{kg}$ DM. Regardless of cultivar, increasing the proportion of faba bean in the mixture resulted in decreasing the NFE content in oat grain, with the lowest values being found in $75 \%$ mixtures.

With the exception of crude ash, there was no statistically significant $(\mathrm{P}>0.05)$ effect of cultivation method on the chemical composition of faba bean seeds (Table 3). There was only a tendency to store more protein in the seeds of Optimal $\mathrm{cv}$., and fat and crude fibre in the seeds of Olga cv. The content of CP ranged from 326 to 343 , NFE from 516 to 527 , crude fibre from 74.6 to 91.8 and ether extract from 14.2 to $20.8 \mathrm{~g} \cdot \mathrm{kg}^{-1} \mathrm{DM}$. 
In vitro true digestibility (IVTD) of naked oat grain was relatively stable and averaged $96.4 \% \pm 0.23 \%$ (Table 4 ). The highest IVTD was observed in grain cultivated in pure sowing, while the lowest, in grains from mixtures M3 and M6, which accounted for $25 \%$ of oats in sowing materials. Irrespective of the method of cultivation, the variety Optimal (high tannin content), which contained more protein, was characterized by a lower average IVTD value than Olga cv. The IVTD of cv. Olga (94.6\%) grown in pure sowing was significantly higher compared with that for cv. Optimal (91.4\%).

Table 4. In vitro true digestibility (IVTD) of oat grains and faba bean seeds cultivated in pure stand or in mixtures

\begin{tabular}{clcc}
\hline \multirow{2}{*}{ Indices } & Origin of & \multicolumn{2}{c}{ In vitro true digestibility, IVTD, \% } \\
\cline { 3 - 4 } & grains/seeds & oat & faba bean \\
\hline Pure stand & oat (Polar) & $96.9^{\mathrm{a}}$ & - \\
& faba bean & & $94.6^{\mathrm{ab}}$ \\
& Olga & - & $91.4^{\mathrm{d}}$ \\
Optimal & & \\
Mixtures & & $96.2^{\mathrm{bc}}$ & $95.9^{\mathrm{a}}$ \\
M1 & faba bean & $96.4^{\mathrm{abc}}$ & $94.5^{\mathrm{abc}}$ \\
M2 & cultivar & $96.1^{\mathrm{c}}$ & $93.7^{\mathrm{bc}}$ \\
M3 & Olga & & $91.6^{\mathrm{cd}}$ \\
M4 & faba bean & $96.2^{\mathrm{c}}$ & $92.0^{\mathrm{bsd}}$ \\
M5 & cultivar & $96.7^{\mathrm{ab}}$ & $92.6^{\mathrm{bcd}}$ \\
M6 & Optimal & $96.1^{\mathrm{c}}$ & 93.5 \\
& Overall mean & 96.4 & 1.157 \\
& SEM & 0.218 & .
\end{tabular}

a,b... means within a column with different superscripts are significantly different $(\mathrm{P}<0.05)$

The nutritive value of oat grain and faba bean seeds is shown in Table 5 . Higher energy (UFL, UFV) and lower protein (PDIN, PDIE) values were found for oat grain grown in pure sowing in comparison with the grain originating from mixtures. Regardless of cultivar, the energy content of faba bean seeds grown in pure sowing was slightly lower than the faba bean seeds from the mixtures. There was no effect of faba bean cultivation methods (pure sowing vs mixture) on their protein content. A significant $(\mathrm{P}<0.05)$ negative correlation between crude protein content (Figure 2) or crude fibre content (Figure 4) in oat grain and IVTD was found. In the case of faba bean, a high negative correlation $(\mathrm{R} 2=0.80)$ was shown between crude fibre content in seeds and their IVTD (Figures 3 and 5). 
Table 5. Nutritive value of oat grains and faba bean seeds cultivated in pure stand or in mixtures, in $1 \mathrm{~kg}$ of dry matter

\begin{tabular}{|c|c|c|c|c|c|c|}
\hline \multirow{2}{*}{ Cultivar } & \multirow{2}{*}{$\begin{array}{l}\text { Origin of } \\
\text { grains/seeds }\end{array}$} & \multirow{2}{*}{ UFL } & \multirow[b]{2}{*}{ UFV } & PDIN & PDIE & PDIA \\
\hline & & & & \multicolumn{3}{|c|}{$\mathrm{g} \cdot \mathrm{kg}^{-1}$ dry matter } \\
\hline \multirow{9}{*}{$\begin{array}{l}\text { Oat } \\
\text { Polar }\end{array}$} & Pure stand & 1.28 & 1.30 & 93 & 84 & 16 \\
\hline & M1 & 1.26 & 1.27 & 102 & 87 & 18 \\
\hline & M2 & 1.26 & 1.27 & 100 & 86 & 17 \\
\hline & M3 & 1.23 & 1.24 & 107 & 86 & 18 \\
\hline & M4 & 1.23 & 1.24 & 102 & 86 & 18 \\
\hline & M5 & 1.27 & 1.29 & 106 & 87 & 18 \\
\hline & M6 & 1.26 & 1.27 & 111 & 87 & 19 \\
\hline & Mean & 1.26 & 1.27 & 103 & 86 & 18 \\
\hline & SD & 0,02 & 0.02 & 6 & 1 & 1 \\
\hline \multirow{6}{*}{$\begin{array}{l}\text { Faba bean } \\
\text { Olga }\end{array}$} & Pure stand & 1.10 & 1.10 & 211 & 108 & 56 \\
\hline & M1 & 1.11 & 1.12 & 207 & 107 & 55 \\
\hline & M2 & 1.11 & 1.12 & 212 & 109 & 56 \\
\hline & M3 & 1.11 & 1.12 & 213 & 109 & 56 \\
\hline & Mean & 1.11 & 1.12 & 211 & 108 & 56 \\
\hline & SD & 0.01 & 0.01 & 3 & 1 & 1 \\
\hline \multirow{6}{*}{$\begin{array}{l}\text { Faba bean } \\
\text { Optimal }\end{array}$} & Pure stand & 1.10 & 1.10 & 219 & 113 & 61 \\
\hline & M4 & 1.11 & 1.12 & 207 & 107 & 61 \\
\hline & M5 & 1.11 & 1.12 & 218 & 113 & 61 \\
\hline & M6 & 1.10 & 1.11 & 219 & 113 & 61 \\
\hline & Mean & 1.11 & 1.12 & 215 & 111 & 61 \\
\hline & SD & 0.01 & 0.01 & 6 & 3 & 0 \\
\hline
\end{tabular}

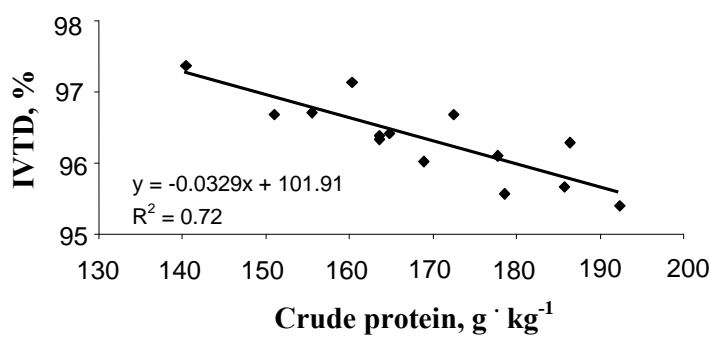

Figure. 2. The relationship between crude protein content in oat grains and their in vitro true digestibility (IVTD)

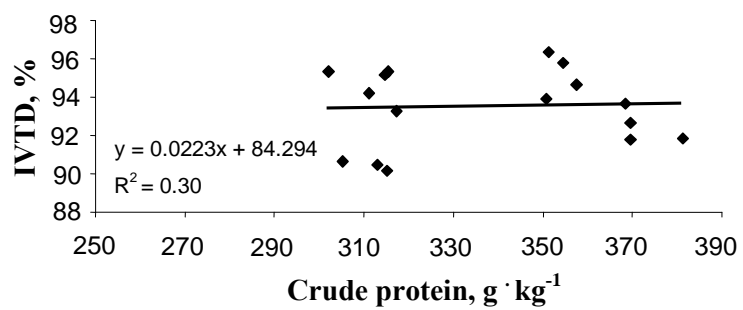

Figure 3. The relationship between crude protein content in faba bean seeds and their in vitro true digestibility (IVTD) 


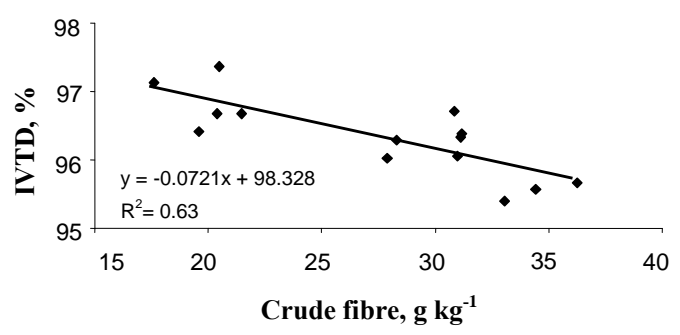

Figure 4. The relationship between crude fibre content in oat grains and their in vitro true digestibility (IVTD)

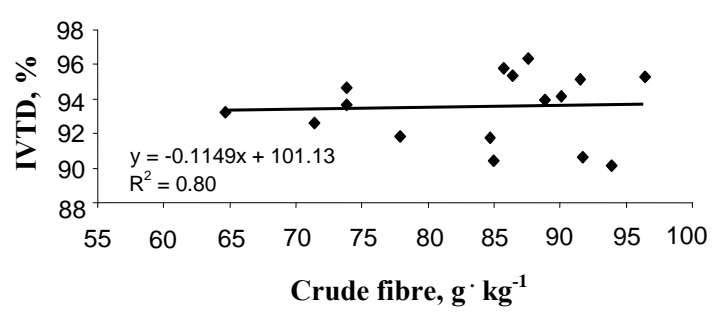

Figure 5. The relationship between crude fibre content in faba bean seeds and their in vitro true digestibility (IVTD)

\section{DISCUSSION}

Plants grown in mixtures are characterized by greater diversity in terms of yield and nutrient content of seeds as a result of morphological and developmental differences, competitive pressures in the canopy, as well as weather conditions. In this study, total grain and seed yields and total protein yield of legume-cereal mixtures were found to depend on the percentage of components in the mixture. Similar relationships were found for other species in studies carried out by Siuta et al. (1998) and Pisulewska et al. (2001). In the current study, the highest average grain, seed, and protein yields were observed in the mixtures with a $75 \%$ share of faba bean, regardless of cultivar. It can be concluded, therefore, that increasing the share of legumes in mixtures with cereals increases the total yield of mixtures per hectare. Our results support those of studies carried out by Księżak (2007) on fodder pea grown with barley. On the other hand, Pisulewska et al. (2001) showed that increasing the share of common vetch in a mixture with oat is followed by a reduction in the total seed yield of the mixtures.

According to Siuta et al. (1998), a deficit of nitrogen in organic farming makes cereals less competitive in relation to legumes. Zielińska and Rutkowski (1988) cultivated oat in mixtures with field pea and obtained a $32 \%$ higher total protein 
yield than when oat was grown in pure sowing. In our experiment, the highest yield of total protein $\left(978 \mathrm{~kg} \cdot \mathrm{ha}^{-1}\right)$ was obtained from a $75 \%$ mixture (Optimal $\mathrm{cv}$.). Increasing the share of legumes in the mixture from $25 \%$ to $75 \%$ resulted in increased protein yield per hectare. This confirms the previous studies by Kulig and Szafrański (2001), who showed that the yield of protein mixtures with a $75 \%$ share of faba bean (cv. Optimal) and $25 \%$ share of spring wheat or triticale were higher than the yields of those components obtained from pure stands. These results are also consistent with studies of Ceglarek et al. (1997), who recommend a mixture of spring wheat with $75 \%$ of faba bean for planting in agricultural practice in order to obtain the highest seed and protein yields.

In our study, as well as in experiments of other authors (e.g., Ceglarek et al., 1997), the chemical composition of legume-cereal mixtures changed due to variable proportions of legumes in sowing material. Faba bean seeds grown in pure sowing are usually characterized by lower concentrations of crude protein, crude fat, and $\mathrm{N}$-free extractives as compared with those from mixtures. On the other hand, Ceglarek et al. (2007) examined mixtures of vetch with oat and showed that vetch seeds cultivated in pure sowing have higher concentrations of protein, fat, and fibre and lower carbohydrate contents. Szpunar-Krok et al. (2006) reported that the content of protein and fibre in faba bean seeds remained at the same level in plants grown in pure sowing and in mixtures with triticale.

In our experiment, the content of protein in the seeds of faba bean cultivars ranged from 332 to $343 \mathrm{~g} \cdot \mathrm{kg}^{-1} \mathrm{DM}$. A higher range of protein content in faba bean seeds (247-372 $\left.\mathrm{g} \cdot \mathrm{kg}^{-1} \mathrm{DM}\right)$ was reported by Duc et al. (1999). At the same time, a lower crude protein content compared with the Optimal variety was found in the seeds of the low-tannin variety (Olga), which is consistent with the results of Frejnagel et al. (1997). In their study, the low-tannin variety (Caspar) was characterized by a lower protein content than the Tinos variety (determinate, high tannin content) and the indeterminate Nadwiślański variety. It should be noted, however, that studies described by Duc et al. (1999) and Crépon et al. (2010) conducted on larger number of genotypes showed that low-tannin varieties contain more protein than cultivars with a high tannin content.

In the current study, the crude protein content in oat grain was inversely proportional to the percentage of oat in the sowing material. A similar trend was observed by Kulig and Szafranski (2001), who studied faba bean mixtures with wheat or spring triticale. This relationship follows from the fact that nonlegume plants growing in the vicinity of legumes benefit from the nitrogen assimilated by the bacteria. This was confirmed in a model study conducted by Xiao et al. (2004), who demonstrated an increased concentration of nitrogen in the shoots of wheat cultivated in mixtures with faba bean. The same tendency was observed by Szpunar-Krok et al. (2006) in mixtures of faba bean with triticale. 
Probably for this reason we observed the highest protein content in oat grain (182 $\mathrm{g} \cdot \mathrm{kg}^{-1} \mathrm{DM}$ ) in $75 \%$ mixtures. The content of crude protein in oat grain from pure sowing was similar as found by Piątkowska et al. (2010) in the Polar variety. In turn, Biel et al. (2009) reported that, depending on genotype, the protein content in oat grain ranged from 126 to 172 and crude fibre from 20.6 to $34.8 \mathrm{~g} \cdot \mathrm{kg}^{-1} \mathrm{DM}$.

It was demonstrated that in vitro true digestibility of faba bean seeds depended more on its share in mixtures than observed for oat grain. The higher digestibility of oat than faba bean was probably due to its higher $\mathrm{N}$-free extractives content and lower content of crude fibre. Due to trace amounts of hulls in naked oat, its crude fibre content was low and this contributed to the high grain digestibility. The presence of antinutritional factors, mainly tannins, could also have a significant impact on the IVTD of faba bean by forming insoluble complexes with protein, thus inhibiting its digestion and, consequently, reducing its digestibility (Duc et al., 1999; Crépon et al., 2010). In the present study, the seeds of the low-tannin faba bean cultivar (Olga) were characterized by a higher digestibility as compared with the high-tannin cv. Optimal. This corroborates the earlier observations by Frejnagel et al. (1997), Micek et al. (2009) and Crépon et al. (2010) who demonstrated significantly lower values of IVTD in the seeds of high-tannin cultivars. The calculated net energy value of faba bean seeds (UFL, UFV) was slightly lower than presented by Crépon et al. (2010), while the protein values (PDIN, PDIE) did not differ significantly.

\section{CONCLUSIONS}

Total grain and seed and protein yield per ha of faba bean and oat mixtures depended on the percentage of these species in the sowing material. The best results were obtained with $75 \%$ of faba bean and $25 \%$ of oat. Increasing the proportion of faba bean in a mixture significantly increased the crude protein content in oat grain, but had little effect on the chemical composition of faba bean seeds.

The in vitro true digestibility of oat grain and faba bean seeds did not depend on mixture composition. Faba bean digestibility was influenced much more by cultivar than by its proportion in the sowing material.

In organic farming systems, cultivation of faba bean and naked oat in mixtures is more suitable for feed production than the cultivation of these species separately.

\section{REFERENCES}

Ankom Technology, 2009. In vitro True Digestibility Using the Daisy II Incubator. Retrieved in 2009 from http:/www.ankom.com 
AOAC, 2001. Association of Official Analytical Chemists, Official Methods of Analysis. 17 $7^{\text {th }}$ Edition. Arlington, VA

Baranowski A., 2005. Faba bean seeds in feeding of fattening bulls (in Polish). Prz. hod. 72 (8), 11-12

Bidwell-Porębska K., Piotrowski J., 1991. Faba bean and lupine seeds in concentrate mixtures for young calves (in Polish). Prz. hod. 59 (2), 16-18

Biel W., Bobko K., Maciorowski R., 2009. Chemical composition and nutritive value of husked and naked oat grain. J. Cereal Sci. 49, 413-418

Borowiecki J., Księżak J., 2000. Legumes in mixtures with cereals in feed production (in Polish). Post. Nauk rol. 47 (2), 89-100

Ceglarek F., Brodawski F., Buraczyńska D., Płaza A., 1997. Yielding of faba bean mixtures with spring wheat in conditions of central-eastern Poland (in Polish). Zesz. probl. Post. Nauk rol. 446, 383-387

Ceglarek F., Rudziński R., Płaza A., Buraczyńska D., 2007. Nutritive value of common vetch (Vicia sativa L.) grown in pure and mixed stands in the middle-east Poland (in Polish). Zesz. probl. Post. Nauk rol. 516, 19-26

Crépon K., Marget P., Peyronet C., Carrouée B., Arese P., Duc G., 2010. Nutritional value of faba bean (Vicia faba L.) seeds for feed and food. Field Crop Res. 115, 329-339

Duc G., Marget P., Esnault R., Le Guen J., Bastianelli A., 1999. Genetic variability for feeding value of faba bean seeds (Vicia faba): Comparative chemical composition of isogenic involving zerotannin and zero-vicine genes. J. Agr. Sci. 133, 185-196

Frejnagel S., Zduńczyk Z., Krefft B., 1997. The chemical composition and nutritive value of lowand high-tannin faba bean varieties. J. Anim. Feed Sci. 6, 401-412

INRA, 2007. Alimentation des Bovins, Ovins et Caprins. Besoins des Animaux - Valeurs des Aliments. Tables INRA 2007. Editions Quae (France)

Księżak J., 2007. The development of pea and spring barley plants in the mixtures on various soil types (in Polish). Zesz. probl. Post. Nauk rol. 516, 93-90

Kulig B., Szafrański W., 2001. Yielding of two different faba bean morphological types cultivated as pure stands or in mixtures with spring wheat and triticale (in Polish). Acta Agr. Silv., Ser. Agr. XXXIX, 3-15

Kulig B., Zając T., 2007. Biological and agrotechnical conditions of faba bean productivity (in Polish). Post. Nauk rol. 54 (1), 63-80

Maierhofer R., Obermaier A., Hitzlsperger L., Spann B., 2002. Einsatz von Erbsen und Ackerbohnen in der Mast von Bullen mit Mischrationen. Forum Angewandte Forschung in der Rinder-und Schweinefutterung. Tagungsunterlage. Fulda (genes), pp. 26-29

Micek P., Kowalski Z.M., Kulig B., Walerowski F., 2009. Effect of variety and type of plant protection on chemical composition and in vitro digestibility of faba bean seeds. In: Proceedings of the National Conference Genetically modified feeds (GMO) and conventional feeds in animal nutrition. Editor: National Research Institute of Animal Production, Krakow, pp. 361-362

Noworolnik K., Leszczyńska D., 2004. Suitability of naked and husked cultivars of spring barley and oats for intercropping (in Polish). Pam. Puł. 138, 109-116

Pastuszewska B., 1997. The nutritive value of legume seeds in animal nutrition (in Polish). Zesz. probl. Post. Nauk rol. 446, 83-94

Piątkowska E., Witkowicz R., Pisulewska E., 2010. Basic chemical composition of selected cultivars of oats (in Polish). Żywność, Nauka, Technol., Jakość 3, 70, 88-99

Piech M., Nita Z., Maciorowski R., 2000. Comparison of usefulness of naked and hulled oats for growing in mixtures with barley. Rocz. AR Poznań Ser. Roln. 58, 89-97 
Pisulewska E., Klima K., Poradowski R., 2001. Yielding and chemical composition of oat grains grown with undersown spring vetches in a mountain region (in Polish). Acta Agr. Silv., Ser. Agr. XXXIX, 137-147

SAS, 1999-2000. SAS/STAT User's Guide, release 8.1, SAS Institute Inc. Cary, NC

Siuta A., Dworakowski T., Kuźnicki J., 1998. Grain yields and forecrop value of cereal mixtures with leguminous for cereals in conditions of ecological farms (in Polish). Fragm. Agron. 2, 53-62

Szpunar-Krok E., Bobrecka-Jamro D., Kubit P., 2006. Effect of faba bean as a component of mixture on chemical composition of spring triticale grain (in Polish). Folia Univ. Agr. Stetinensis, Agr. 247, 201-206

Van Soest P.J., Wine R.H., Moore L.A., 1966. Estimation of the true digestibility of forages by the in vitro digestion of cell walls. In: Proceeding of the Xth International Grassland Congress, Helsinki. Finnish Grassland Association. Helsinki, pp. 438-441

Xiao Y., Li L., Zhang F., 2004. Effect of root contact on interspecific competition and $\mathrm{N}$ transfer between wheat and faba bean using direct and indirect ${ }^{15} \mathrm{~N}$ techniques. Plant Soil 262, 45-54

Zielińska A., Rutkowski M., 1988. Comparison of performance of oats, barley and four field peas cultivars grown in pure stand or in mixtures (in Polish). Acta Acad. Agr. Tech. Olst., Agric. 46, 113-124 